\title{
Vesicovaginal fistula: Do the patients know the cause?
}

\section{Page $\mid 122$}

M. A. Hassan, B. A. Ekele

Department of Obstetrics and Gynaecology, Usmanu Danfodiyo University Teaching Hospital, Sokoto, Nigeria

Correspondenceto: Dr Mairo. A. Hassan, Department of Obstetrics and Gynaecology, Usmanu Danfodiyo University Teaching Hospital, Sokoto, Nigeria. E-mail: mayroh123@ yahoo.com

\begin{abstract}
Background: So much has been written on vesicovaginal fistula (WF) but there is little on the patients' perspective of the condition. The objectives of this study were to determine the knowledge of patients who have developed WF on the causes of the fistula and their attitude toward measures that would prevent future occurrence.

Methods: The questionnaire-based survey was conducted on WF patients on admission from June to August 2003 at Maryam Abacha Women and Children Welfare Hospital, Sokoto, Nigeria. The case notes of the patients were reviewed after the interview to match the responses from the patients with those documented in the folders. Focus group discussions were held with the maternity staff to ascertain the content and quality of existing counseling.

Results: One hundred and thirty patients were studied out of which $121(93 \%)$ had no formal education. Teenagers constituted $37 \%$, while $57 \%$ were primiparae. Thirty-five (27\%) patients were divorced or separated because of the WF. There were seven cases of recurrence after a previous successful repair. Prolonged obstructed labor was the cause of the WF in 110 (85\%) patients and 77 (70\%) correctly attributed their problem to the prolonged labor. The 33 patients who could not identify the prolonged obstructed labor as the cause either attributed their condition to God/destiny or to the operation that was done to relief the obstruction and therefore would not have hospital delivery in their subsequent pregnancies. From the focus group discussions, it was confirmed that pre and post-operative counseling were inadequate.

Conclusion: Even though majority (70\%) of the patients knew the cause of their fistula from the health talks, some (32\%) would still not change from risky obstetric behavior. Mandatory provision of accurate and appropriate information and education to all WF patients and their relatives or spouses by trained counselors should be ensured. Such information and education should emphasize the etiology and management of obstetric fistula in order to prevent a recurrence.
\end{abstract}

Keywords: Cause, knowledge, patients, vesicovaginal fistula

\section{Résumé}

arrière-plan: a so beaucoup écrit sur la fistule vesicovaginal (WF) il y a peu sur les patients ' perspective de la condition. Les objectifs de cette étude étaient to déterminer les connaissances des patients qui ont développé WF sur les causes de la fistule et leur attitude vis-à-vis des mesures qui empêcherait l'avenir accident.

méthodes: L'enquête basée sur le questionnaire a été réalisée sur WF patients sur l'admission de Juin à août 2003 Maryam Abacha femmes et enfants Welfare Hospital, Sokoto, au Nigéria. Les notes de cas des patients ont été examinées après l'entrevue à correspond aux réponses provenant des patients avec ceux décrits dans les dossiers. Discussions de groupe de discussion ont eu lieu avec le personnel maternité afin de déterminer la contenu et la qualité de counseling existant.

résultats: Cent trente patients ont été étudiés dont 121 (93\%) n'avaient pas éducation formelle. Adolescents constituaient $37 \%$, alors que $57 \%$ étaient primiparae. Trente cinq patients (27 \%) étaient divorcés ou séparés en raison de la WV. il y avait sept cas de récidive après une précédente réussies de réparation. Prolongée labor gêné était la cause de la WF dans 110 patients (85\%) et 77 (70 \%) correctement attribué leur problème pour le travail prolongé. Les 33 patients qui pourrait pas d'identifier le labor obstruée prolongée comme la cause soit attribuée leur condition à Dieu/Destiny ou à l'opération a été faite à un redressement l'obstruction et par conséquent pas 
aurait livraison de l'hôpital leur grossesses ultérieures. Des groupes de discussion, il a été confirmé que pré et postopératoires counseling étaient inadéquats.

conclusion: Même si la majorité (70 \%) des patients savait que la cause de leur fistule de les pourparlers de santé, certains (32\%) toujours pas changerait de risqué obstétrique comportement. Mise à disposition obligatoire de précis et appropriées des informations et l'éducation à tous les patients WV et leurs relations ou conjoints par formés. conseillers devraient être assurées. ces informations et l'éducation devraient souligner l'étiologie et la gestion de fistule obstétrique afin d'empêcher une récurrence.

Mots cles: Vesicovaginal fistule, patients, la connaissance, cause

DOI: $10.4103 / 1596-3519.56241$

PMID: 19805944

\section{Introduction}

Vesicovaginal fistula (VVF) is still a major problem in developing countries. Three out of every 1000 deliveries in West African countries develop VVF and about 200,000 women await surgical repair in Nigeria alone. ${ }^{[1-4]}$ The prevalence of VVF is often underestimated because knowledge of the number of sufferers is linked to those who come to hospital for treatment. There are patients with the condition who suffer silence and isolation. The magnitude of the condition in northern Nigeria in particular is such that some of the largest numbers of cases reported in the literature are from the region. ${ }^{[5,6]}$

The etiologies of VVF are much different in the developed world as compared with the developing world. VVF from prolonged obstructed labor is rarely seen in the affluent, industrialized world yet it continues to exist in epidemic proportion in sub-Saharan Africa. In Nigeria for instance, VVF sequel to obstructed labor may account for as high as $96.5 \%$ of cases. ${ }^{[6]}$

A number of biological, social, 1 and environmental factors contribute to the high prevalence of VVF. For instance, poor women get fistulas partly because of their inability to promptly access obstetric services and the poorer the woman, the greater her likelihood of dying or suffering a catastrophic obstetric complication. Indeed, it is said that obstetric fistulas result from a combination of obstructed labor and 'obstructed transportation' as articulated in the model of three stages of delay. ${ }^{[7]}$ The very poor, young, illiterate, rural girls and women have been associated with obstetric fistulas in the developing countries. ${ }^{[8]}$

Extensive publications ${ }^{[9-12]}$ already exist on the epidemiological characteristics and surgical management of the condition but there is very little on the patient understanding of the condition. Such information is essential for effective preventive measures and strategies especially for cases of reoccurrence.
Sokoto, the place of the study is an urban city in northern Nigeria, populated predominantly by Hausa-Fulani of the Islamic faith. Most of the indigenous people are farmers and nomads. The practice of Purdah (wife seclusion) is common and the consent of the husband is mandatory before she can leave the house for whatever reason. The objectives of this survey were to determine the knowledge, attitude, and perception of patients with VVF on the causes of the condition and recommend appropriate remedial measures to prevent occurrence.

\section{Materials and Methods}

Maryam Abacha Women and Children Hospital, Sokoto, is a state-owned hospital that is dedicated primarily to VVF patients. Services at the health facility are free including surgical operations that are carried out mainly by visiting specialists that come from outside the state on scheduled days. American and European specialists also come as volunteers on short-term trips to perform fistula repair operations at the hospital. ${ }^{[13]}$

After obtaining institutional permission and consent of the patients, one of the authors (MAH) administered pre-tested questionnaire on all the VVF patients who were on admission awaiting surgery or recovering from surgery from June to August 2003, on a one-on-one basis. It was a purposive sampling. The questionnaire [Figure 1] included information on biosocial data, what the patient considers as the cause of her fistula and her future plan with regards to pregnancy and delivery. The case note of each patient was reviewed at the end of the interview for information on the cause and management of the fistula. This was then matched with the patient's response in order to determine if her knowledge in relation to the cause of her fistula was correct.

Focus group discussions were then held in small groups of five that included the three medical 


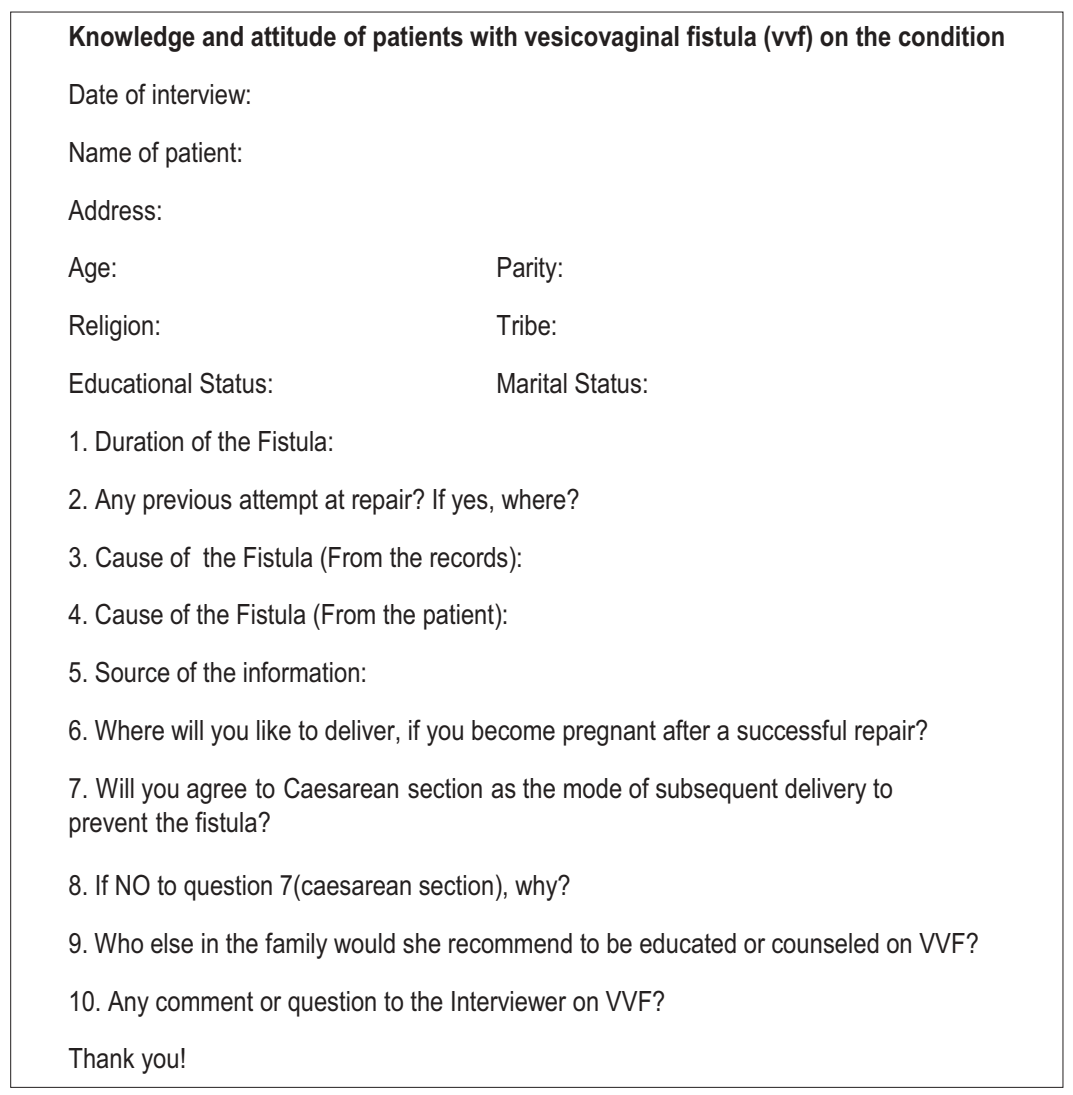

Figure 1: The questionnaire

officers attached to the maternity ward and all the nurses who work in the VVF ward. There were three sessions and the last one was specifically for the nurses who were not on duty when the first two were held. The question guide covered the type, content, and quality of counseling that is provided before and after surgery. BAE was the moderator, while MAH was the recorder and note keeper. Analysis of the responses of the staff was by simple interpretation, and translation were necessary without the recourse to coding since the issue was just who does the counseling and content.

Patients' responses to the causes of their fistula are presented and analyzed in tables.

\section{Results}

One hundred and thirty patients were interviewed during the study period. Of them, 96 were awaiting surgery, while 34 were recuperating from surgical repair. One hundred and twenty-one patients (93\%) were of the Hausa-Fulani ethnic group and 125 (96\%) of them were housewives with no formal education. Of the total, 74 (57\%) patients were primiparae. Of total, 48 (37\%) were teenagers, while $35(27 \%)$ were either divorced or separated. There were seven cases of re-occurrence of the fistula after previous successful repair.
Table 1 shows the causes and the patients' knowledge. A $70 \%$ of those who had prolonged obstetric labor correctly identified the cause.

The 33 patients who could not identify prolonged obstructed labor as the cause of their fistula gave various reasons for the fistula as shown in Table 2.

Some questions on the questionnaire sought to establish the future obstetric behavior of the

\begin{tabular}{|c|c|c|c|}
\hline Causes & $\begin{array}{l}\text { From } \\
\text { the } \\
\text { case } \\
\text { notes / } \\
\text { records }\end{array}$ & $\begin{array}{l}\text { No of patients } \\
\text { with correct } \\
\text { knowledge } \\
\text { from } \\
\text { interview }\end{array}$ & $\begin{array}{l}\% \text { Correct } \\
\text { knowledge }\end{array}$ \\
\hline $\begin{array}{l}\text { Prolonged } \\
\text { obstructed } \\
\text { labor }\end{array}$ & 110 & $77^{a}$ & 70 \\
\hline $\begin{array}{l}\text { Female genital } \\
\text { mutilation }\end{array}$ & $5^{b}$ & 3 & 60 \\
\hline latrogenic & 5 & 4 & 80 \\
\hline Measles & 2 & 2 & 100 \\
\hline $\begin{array}{l}\text { Not indicated / } \\
\text { indeterminate }\end{array}$ & 8 & 0 & 0 \\
\hline Total & 130 & 86 & \\
\hline \multicolumn{4}{|c|}{$\begin{array}{l}\text { a23 (30\%) out of the } 77 \text { patients that correctly identified } \\
\text { prolonged obstructed labor as the cause of their fistula also } \\
\text { added God/Destiny as responsible for the disorder. } \\
{ }^{b} 2(1.5 \%) \text { cases were from Gishiri cut. }\end{array}$} \\
\hline
\end{tabular}


Table 2: Analysis of the wrong causes given by patients that had prolonged obstructed labor

\begin{tabular}{lc}
\hline Causes & No. of patients \\
\hline God/destiny & 16 \\
aOperations/procedure in hospital & 7 \\
Others (vaginal exam, episiotomy) & 2 \\
"Do not know" & 8 \\
Total & 33 \\
\hline aperations refer to procedures performed to relief obstruction \\
like Caesarean section or craniotomy.
\end{tabular}

patients. For example, they were asked: "W herewill you like to deliver if you become pregnant after a succesful repair?" Out of the 110 patients who had prolonged obstructed labor as cause, 75 (68\%) will have hospital delivery, $11(10 \%)$ will have unsupervised home delivery, while $24(22 \%)$ patients said they did not know because the decision was not theirs.

To the question: "W ill you agreeto a $\mathrm{C}$ aesarean section as the mode of subsequent delivery to prevent the fistula?," 61 $(55.5 \%)$ patients will consent to Caesarean section, $15(13.6 \%)$ will not accept it, while 34 (30.9\%) could not make any personal commitment.

From the focus group discussions with the medical officers and nurses who attend to the patients, it was found that there was no trained or designated counselor in the unit. Any of the most senior nurses on duty for the day would give general health talk including causes of VVF to the patients before surgery. Information is also provided on immediate post-operative care and the management of subsequent pregnancies before the discharge of the patients. There is, however, no policy that compels patients, relatives, or spouses to attend such counseling sessions and there are no specific guidelines or topics just as there is no specific time for the sessions.

\section{Discussion}

Most of the cases of VVF in this survey were among the young, uneducated, primiparae. Previous studies from around the same area have reported similar findings. ${ }^{[14-16]}$ However, the divorce rate of $27 \%$ that was found in this work was much lower than the $55 \%$ earlier reported by Ibrahim et al. ${ }^{[16]}$

Prolonged obstructed labor remains the single most important cause of the fistula (85\%) and has been demonstrated consistently in most reports from the West African sub-region. ${ }^{[3,9,14,15,17,18]} \mathrm{G}$ ishiri cut (traditional practice of cutting the vagina with sharp instrument) accounted for just two cases (1.5\%) in this study when compared to the $13 \%$ reported from the Zaria area ${ }^{[5]}$ or the $6.2 \%$ found at Maiduguri. ${ }^{[9]}$
It is either because the practice of $\mathrm{G}$ ishiri cut is not common in the Sokoto area or that the incidence is falling with increasing awareness of its dangers. Both reasons might be applicable for Ghatak, who found that only $3.3 \%$ of cases attributable to $G$ ishiri cut in his study of over 15 years ago. ${ }^{[14]}$

Seventy percent of respondents correctly identified the causes of their fistulae from health talks that they have had while on admission. What could not be guaranteed was whether this knowledge would be put to practice in a subsequent pregnancy and labor especially for those who had prolonged obstructed labor? Indeed, there was a disparity between this knowledge and future obstetric behavior of the respondents, as $45 \%$ would either not agree to a Caesarean section or would not take responsibility for such a decision.

The problems that confront a VVF patient are many and have been aptly described as 'one calamity too many'. ${ }^{[19]}$ Therefore, one would have expected wholesome acceptance of preventive measures including abdominal delivery in subsequent pregnancies but that was not the case from this survey. In fact, at the time of the study, there were seven cases of re-occurrence after previous successful surgical repair on admission awaiting repeat surgery. This issue was also corroborated in a United Nations Population Fund (UNFPA) report that stated that more than $5 \%$ of fistulas at one site in northern Nigeria were recurrences. ${ }^{[20]}$ Overcoming this problem might not be easy. Formal education is one sure long-term answer. ${ }^{[21]}$ However, a shortterm approach would be to help the patient and her relatives to make informed and responsible choices during subsequent pregnancies.

One of the social contributors to VVF is the lack of decision-making power available to the women, even on issues pertaining to their own health. ${ }^{[5,21]}$ Until such a time when women in the developing countries are liberated and empowered both in knowledge and economically, we should have polices and strategies that involve their husbands and relatives. Such an opportunity is created when a patient is on admission awaiting surgical repair of the fistula. It should be the right time to impress on the relatives (for they are responsible for decision making) of the dangers of subsequent vaginal deliveries and how it may be difficult if not impossible to repair cases of recurrence.

That some of the patients on admission awaiting surgery did not know the immediate cause of their fistula is not as instructive as the findings of wrongly alluding cause to hospital procedures and/or the interventions to relief obstruction. Therefore, the 
content of any formal counseling session before and after surgical repairs should address fears and misconceptions that patients may have. For instance, patients should be told during such sessions that vaginal examination and episiotomy do not cause VVF. No doubt, the provision of accurate information can lead to increased acceptance of hospital deliveries. Also, God/destiny as a cause of fistulae should be discountenanced. Respected clerics could be employed on a part-time basis as counselors to handle this aspect during the waiting period. The general duty nurse or midwife or the surgeon, might not be the appropriate counselor on issues that bother on faith, religion or God.

We could also use the waiting period (which may be up to 8 weeks) to improve the patient's knowledge using audio-visuals that are culturally sensitive. "WHY DID MRS X DIE?" a WHO video presentation is an example of a short narration that can touch even the most difficult of hearts. We could have something similar, titled "WHY DID MRS X DEVELOP VVF?" The effects of such a session in which the narration is done in the native language of the community would be enormous, especially if it incorporates all the possible outlets that can prevent the development of VVF, so that patients (and relations) can make informed choices. This can be complimented by the use of "praise songs." ${ }^{[22]} \mathrm{We}$ cannot but agree with the submission of Ahmed et al. that making policies, plans, and decisions in the absence of information is outrageous when issues are complex. ${ }^{[23]}$ Melah et al, have also highlighted the importance of media- and community-based programs using cultural and religiously-based values to give sound advice. ${ }^{[2]}$ We need a holistic approach to VVF!

In conclusion, the principal cause of VVF in the study area was prolonged obstructed labor. Although majority of the patients identified the correct cause of their condition, there was a disparity between the knowledge and their attitude toward future obstetric behavior that could lead to VVF. It is recommended that during the course of treatment, skilled counselors should be used to sensitize and provide information and education to the patients and their relatives so that they become agents of change to themselves and possibly to their various communities.

\section{References}

1. Hilton P, Ward A. Epidemiological and surgical aspects of urogenital fistulae: A review of 25 years experience in southeast Nigeria. Int Urogynecol J Pelvic Floor Dysfunct
1998:9:189-94.

2. Kelly J. Vesicovaginal fistula: The burden of maternal ill health. Safe Mother 1999;27:5-7.

3. Danso KA, MarteyJO, Wall LL, ElkinsTE. The epidemiology of genitourinary fistulae in Kumasi, Ghana, 1977-1992. Int Urogyecol J Pelvic Floor Dysfunct 1996;7:117-20.

4. Ojengbende AO. Bladder capacity, maximum urethral length and stress urinary incontinence in repaired vesicovaginal fistulae. Trop J Obstet Gynecol 1996;13:258.

5. Tahzib F. Epidemiological determinants of vesicovaginal fistulas. Br J Obstet Gynaecol 1983;90:387-91.

6. Wall LL, Karshima JA, Kirschner C, Arrowsmith SD. The obstetric vesicovaginal fistula: Characteristics of 899 patients from Jos, Nigeria. Am J Obstet Gynecol 2004;190:1011-9

7. Thaddeus S, Maine D. Too far to walk: Maternal mortality in context. Soc Sci Med 1994;38:1091-110.

8. Muleta M. Obstetric fistula in developing countries: A review article. J Obstet Gynaecol Can 2006;28:962-6.

9. Ampofo K, Otu T, Uchebo G. Epidemiology of vesicovaginal fistulae in northern Nigeria. West Afr J Med 1990;9:98-102.

10. Ojanuga OD, Ekwempu CC. An investigation of sociomedical risk factors associated with vaginal fistula in northern Nigeria. Women Health 1999;28:103-16.

11. Ijaiya MA, Aboyeji PA. Obstetric urogenital fistula: The Ilorin experience, Nigeria. West AfrJ Med 2004;23:7-9.

12. Waaldijk K. The immediate management of fresh obstetric fistulas. Am J Obstet Gynecol 2004;191:795-9.

13. Wall LL, Arrowsmith SD, LasseyAT, Danso K. Humanitarian ventures or 'fistula tourism?' the ethical perils of pelvic surgery in the developing world. Int Urogynecol J Pelvic Floor Dysfunct 2006;17:559-62.

14. Ghatak DP. A study of urinary fistulae in Sokoto, Nigeria. J Indian Med Assoc 1992;90:285-7.

15. Ekele BA, Dikko AA. Urogenital fistulae in Sokoto. Trop J Obstet Gynecol 1997;14:43-5.

16. Ibrahim T, Sadiq AU, Daniel SO. Characteristics of WF patients as seen at the Specialist Hospital, Sokoto, Nigeria. West Afr J Med 2000;19:59-63.

17. Murphy M. Social consequences of vesico-vaginal fistula in northern Nigeria. J Biosoc Sci 1981;13:139-50.

18. Kabir M, Iliyasu Z, Abubakar SI, Umar UI. Medico-social problems of patients with vesico-vaginal fistulae in Murtala Mohammed Specialist Kano. Ann Afr Med 2003;2:54-7.

19. Harrison KA. Commentary: Obstetric fistula: One social calamity, too many problems. Br J Obstet Gynaecol 1983;90:385-6.

20. UNFPA. Obstetric fistula needs assessment: Findings from nine African countries. New York: United Nations Population Fund (UNFPA); 2003.

21. Harrison KA. The importance of the educated healthy women in Africa. Lancet 1997;349:644-64.

22. Wall LL. Fitsari ‘Dan Duniya: An African (Hausa) praise song about vesicovaginal fistulas. Obstet Gynecol 2002;100:1328-32.

23. Ahmad S, Nishtar A, Hafeez GA, Khan Z. Management of vesico-vaginal fistulas in women. Int J Gynecol Obstet 2005;88:71-5.

24. Melah GS, Massa AA, Yahaya UR, Bukar M, Kizaya DD, El-Nafaty AU. Risk factors for obstetric fistulae in northeastern Nigeria. J Obstet Gynaecol 2007;27:819-23.

Source of Support: Nil, Conflict of Interest: None declared. 